\title{
Potential synergy between adaptation and mitigation strategies: production of vegetable oils and biodiesel in northeastern Brazil
}

\author{
Emilio Lèbre La Rovere*, Ana Carolina Avzaradel, Joyce Maria Guimarães Monteiro
}

Center for Integrated Studies on Climate Change and the Environment, at COPPE/UFRJ_Institute for Research and Postgraduate Studies of Engineering, Federal University of Rio de Janeiro, CT, sala I-208, Ilha do Fundão, Rio de Janeiro, RJ, Brazil

\begin{abstract}
In this study we discuss the potential of integrated adaptation and mitigation strategies to addess problems arising from climate change. This 'Ad-Mit' or 'Mit-Ad' approach is illustrated through the case of crop diversification by family farmers to crops used for vegetable oil and biodiesel production in the northeastern semi-arid region of Brazil. Impact assessments of some climate change scenarios indicate this region to be one of the most vulnerable in the country. Small farmers from the northeastern semi-arid region are among the low-income social groups most vulnerable to climate change. Improvement of the social and economic conditions in these rural communities through the growth of vegetable oil crops is an important adaptation strategy vis-à-vis future climate change, constituting an income-generation activity in the biodiesel production chain. The use of vegetable oils as a feedstock for biodiesel production and fuel reduces $\mathrm{CO}_{2}$ emissions due to the displacement of diesel oil, thus it also contributes to a mitigation strategy. Potential barriers to an increase in vegetable oil production by small farmers in the region are identified, including capacity building and logistics requirements. We discuss public policies and measures that could help overcome these barriers in the northeastern semi-arid region, and suggest the following: the use of selected seeds of several vegetable oil crops alongside subsistence crops, capacity building and technological and financial support to small farmers, and the building of logistics infrastructure and the appropriate institutional setting.
\end{abstract}

KEY WORDS: Climate change $\cdot$ Mitigation $\cdot$ Adaptation $\cdot$ Biodiesel $\cdot$ Agriculture $\cdot$ Brazil

\section{INTRODUCTION}

Impact assessments of some climate change scenarios have identified the northeastern region of Brazil as one of the most vulnerable in the country (IPCC 2007). This region has a dry climate and an irregular rainfall distribution, with a history of chronic droughts. Moreover, the El Niño South Oscillation (ENSO) can enhance the severity and frequency of these droughts. Small farmers from the northeastern semi-arid region are among the social groups most vulnerable to climate change. Improvement of the social and economic conditions of these rural communities through the growth of vegetable oil crops is an important adaptation strategy visà-vis future climate change, constituting an income generation activity in the biodiesel production chain.

Recently, the Brazilian government started the National Program for the Production and Use of Biodiesel (PNPB) as a substitute for imported diesel oil, acknowledging that public policies and significant investments are essential to promote economies of scale and facilitate the introduction of this innovation (La Rovere et al. 2008). In the first stage of the program, diesel oil was blended with $2 \%$ biodiesel in 
2007. This blend level was increased to $3 \%$ from July 2008 onwards and is scheduled to reach 5\% in 2012. The PNPB explicitly targets sustainable production of biodiesel in Brazil, promoting social inclusion of small farmers. The requirement of a social fuel certificate (SFC) to benefit from tax reductions was established by the federal government as a mechanism for fostering job generation and including small farmers in the biodiesel production chain. With SFCs, the government seeks to promote partnerships between family farmers and industrial producers who, in order to obtain the SFC, are required to meet basic social requirements - such as technical assistance to family farmers - and to purchase minimum volumes of raw material from these farmers, in order to get the SFC. Decree 6.458, of 14 May 2008, grants the maximum tax reduction rates for biodiesel from raw materials produced by family farmers in the northern, northeastern and other semi-arid regions. It encourages the production of biodiesel feedstocks suited to the climate conditions of the poorer regions of the country, such as castor bean in the northeast and palm in the north.

Castor bean Ricinus communis has been indicated as a suitable crop for small farmers in the Brazilian northeast, since it is already grown in the region and is adapted to the semi-arid climate. Castor bean can be intercropped with subsistence crops, such as corn and beans, in a manual production system. However, current production of castor beans falls far short of meeting the demand for biodiesel resulting from policies by the Brazilian government. In this initial stage, lack of raw materials may lead biodiesel producers to use soybean oil for biodiesel production. As soybean is produced in large agribusiness plantations, social benefits, such as job creation and income generation for the rural population, would be severely limited. Several initial attempts to implement biodiesel production involving family farmers have failed in Brazil. Many barriers must be overcome to obtain the social development goals of the program, including logistical complexity throughout the small family farm raw material supply chain, vegetable oil extraction in decentralized units and its transformation into biodiesel through transesterification in larger plants (Monteiro 2007).

This regional case study outlines the requirements for the successful implementation of vegetable oil and biodiesel production in the northeastern semi-arid region of Brazil. Our main objective was to investigate how to improve the feasibility of biodiesel production by small family farmers in this region, thus helping to contribute to their adaptation to climate change and to the mitigation of $\mathrm{CO}_{2}$ emissions in the country. Results highlight the gap between governmental goals and the current status of small farmer involvement in the PNPB.

\section{CURRENT AND FUTURE VULNERABILITY OF THE NORTHEASTERN SEMI-ARID REGION}

The northeast of Brazil covers 1.5 million $\mathrm{km}^{2}$, equivalent to $18.3 \%$ of the country, and includes 9 of the 26 states. The northeast is responsible for approximately $14 \%$ of the Brazilian gross domestic product (GDP) and holds $27.6 \%$ of the total population; in addition, the region has the lowest average per capita GDP, approximately R\$4000 per inhabitant, and the highest income distribution inequality in the country (IBGE 2006). The problem is heightened in the semi-arid region, which covers $56.6 \%$ of the northeast and is inhabited by approximately 25 million people (IBGE 2004). Of the population in semi-arid areas, $40 \%$ (approximately 8 million people) lived in poverty in 2003 (de Carvalho \& dos Santos 2003).

Temperatures in the region are high, with annual averages varying between 20 and $28^{\circ} \mathrm{C}$. Moreover, rainfall is seasonal, occurring in just 3 months and with annual totals varying between 300 and $2000 \mathrm{~mm}$ (average of $800 \mathrm{~mm} \mathrm{yr}^{-1}$ ). The northeastern semi-arid region repeatedly undergoes chronic water shortages (UNDP 2006). According to Freitas (1999), the volume of water evaporated is around 3 times higher than rainfall precipitation, resulting in a soil moisture deficit (2200 mm yr $\mathrm{mm}^{-1}$, considering $750 \mathrm{~mm}$ of annual rainfall).

Agriculture and cattle raising are the main economic activities in the semi-arid area. About $80 \%$ of rural properties in northeastern Brazil are defined as family farms, where people rely mostly on agricultural activities for their livelihood (INCRA/FAO 2000). Poor communities that depend on climate-sensitive resources, such as water supply, are particularly vulnerable and are likely to have more restricted adaptive capacities (IPCC 2007). In a large part of the sertão (semi-arid area in northeastern region), dryland agriculture is the main economic activity. Relying on very basic technologies, traditional techniques are used to take advantage of unfavorable natural conditions.

The average warming rate in 2100, calculated by the Intergovernmental Panel on Climate Change (IPCC) Third Assessment Report using 6 different mathematical models, points to an increase of temperature in the northeast of between 2.2 and $4{ }^{\circ} \mathrm{C}$ (Marengo et al. 2007). A pessimistic temperature scenario that predicts a $4{ }^{\circ} \mathrm{C}$ increase for the northeast, even when combined with a $15 \%$ increase in rainfall, will result in hydrological deficits throughout the year, due to evaporation, making the region inappropriate for dryland agriculture (Marengo 2005). The possible impact of climate change could be felt by regional subsistence agriculture, causing the population to migrate to larger cities (Marengo et al. 2007). 
In relation to continental scale rainfall projections for 2071 to 2100, the figures from the northeastern region are the most reliable, and it can be stated with medium or high confidence that there will be a rainfall reduction in this region (Marengo et al. 2007). The annual hydrological deficiency in the northeast, which occurs during the months of drought, may last for almost the whole year. It has still not been possible to establish reliable scenarios for hydrological regimes at a local scale, which would help to promote public policies to mitigate vulnerabilities and to seek adaptation measures to climate change (Marengo 2005).

Poor farmers, such as those involved in subsistence farming in the northeastern semi-arid region, might be the group most vulnerable to climate change if a combination of projections regarding increased temperatures, a reduction in rainfall and an increase in evaporation rates prove to be correct (Marengo et al. 2007).

\section{BIODIESEL PRODUCTION AND ADAPTATION AND MITIGATION STRATEGIES}

In the semi-arid northeast, agricultural activities represent the means of survival for a large part of the population. The agricultural sector is dynamic and heterogeneous, with the process of technological modernization taking place very rapidly in some regions. Nonetheless, traditional family agriculture still predominates, mostly practiced by low-income farmers (Leite 2005).

Vegetable oil crops that are potentially suited to planting by family farmers in dry areas include peanuts Arachis hypogaea, sesame Sesamum indicum, sunflower Helianthus annuus, cotton Gossypium hirsutum, castor oil Ricinus communis, purging nut Jatropha curcas and oil palm Elaeis guineensis. All these crops, with the exception of cotton and sunflower, can be planted alongside subsistence crops, such as corn and beans. Nevertheless, regionally, only cotton, castor oil and palm oil are planted on commercially competitive scales. Table 1 gives an estimate of crop productivity, oil content, oil productivity and the area required to produce a ton of oil for the selected crops. The minimum productivity considered is the average crop return obtained in the northeast in 2005 (IBGE/ PAM 2005). The maximum productivity refers to the genetic potential of the varieties developed by the Brazilian Agricultural Research Company (EMBRAPA) for northeastern climatic and soil conditions, with a minimum water availability of $600 \mathrm{~mm} \mathrm{yr}^{-1}$.

The potential return of oil in relation to area is illustrated by the amount of land required to produce a ton of oil. The oil obtained from cotton, castor oil, sunflower and sesame requires a greater area of production per ton of oil, while palm oil and peanuts require a maximum of 2 ha. The choice of vegetable oil species suitable to dry land cultivation is fundamental, taking into account the climatic vulnerability of the region, climate change projections and the socio-economic vulnerability of family farmers. The castor bean has proved its resistance to the dry climate of the region. The first year of Petrobras' project to build 3 biodiesel plants in the semi-arid region was marked by a lack of rainfall. Castor beans - which were planted alongside other crops, such as beans (Phaseolus vulgaris and Vigna unguiculata) - were least affected by the dry conditions due to their high resistance to drought. On the other hand, the high viscosity of castor oil is also a barrier to be overcome, if chosen for the production of biodiesel.

Temporary crops such as peanuts, sunflower, castor oil and sesame allow for shared cultivation, crop rotation and a greater use of land, which is indicated for the large majority of family properties in the semi-arid region. Subsistence production is fundamental, and monoculture is not a viable option for the regional family-based agricultural system. The growing of staple foods, such as beans, corn and fruits, is combined with the raising of a small number of animals.

Table 1. Comparative analysis of vegetable oil crop productivity. Sources: IBGE/PAM (2005); data from EMBRAPA in Monteiro (2007); preliminary estimates for purging nut from savy filho (2006)

\begin{tabular}{|lccccc|}
\hline & $\begin{array}{c}\text { Crop productivity }\left(\mathrm{kg} \mathrm{ha}{ }^{-1}\right) \\
\text { Minimum }\end{array}$ & Maximum & $\begin{array}{c}\text { Oil } \\
\text { content } \\
(\%)\end{array}$ & $\begin{array}{c}\text { Oil } \\
\text { productivity } \\
\left(\mathrm{kg} \mathrm{ha}^{-1}\right)\end{array}$ & $\begin{array}{c}\text { Land-use intensity } \\
(\text { ha t }\end{array}$ \\
\hline Arachis hypogaea (peanuts) & 1337 & 1700 & $40-43$ & $535-731$ & $1.4-1.9$ \\
Gossypium hirsutum (cotton) & 400 & 2200 & 15 & $60-330$ & $3.0-16.7$ \\
Ricinus communis (castor oil) & 700 & 1500 & $45-50$ & $315-750$ & $1.3-3.2$ \\
Helianthus annuus (sunflower) & 800 & 1500 & $30-50$ & $240-750$ & $1.3-4.2$ \\
Elaeis guineensis (oil palm) & 4000 & 6000 & $16-22$ & $640-1320$ & $0.8-1.6$ \\
Sesamum indicum (sesame) & 300 & 1500 & $48-58$ & $144-870$ & $1.1-6.9$ \\
Jatropha curcas (purging nut) & 2000 & 12000 & $50-52$ & $1000-6240$ & $0.2-1.0$ \\
\hline
\end{tabular}


The use of vegetable oil crops also has other benefits to the agricultural system:

- peanuts, sesame and sunflower improve the nitrogen availability in the topsoil for other crops,

- sesame releases substances that help to reduce insects,

- sunflower is conducive to simultaneous honey production,

- cotton, sesame and sunflower have relatively high resistance to drought, owing to deep and branching roots.

The PNPB encourages sustainable production of biodiesel in Brazil, at the same time as promoting social development. The creation of the SFC is an attempt to encourage the generation of employment and to include family agriculture in the biodiesel production chain. Companies that produce biodiesel and meet specified social conditions are provided with access to better funding from the Brazilian Social and Economic Development Bank (BNDES) and other financial institutions, and may also take part in biodiesel auctions organized by the Federal Regulatory Agency for Oil and Biofuels (ANP). Production industries that acquire raw materials from family farmers and guarantee preestablished prices will also be entitled to a partial tax waiver.

The demand for vegetable oils has increased considerably in Brazil since 2003, due to the launch of the PNPB, and will reach around 840 million liters of biodiesel in 2008. The government expects that part of this demand will be met through the supply of raw material by family farmers in the north and northeast of the country. This goal is supported by the state governments in the northeastern region, which are trying to encourage social and regional development. This is particularly important in the state of Bahia, which intends to expand biodiesel production in order to meet the PNPB targets internally and also to export biodiesel to other states.

The production of biodiesel opens the possibility of a local productive chain capable of stimulating economic and social development. Furthermore, the planting of vegetable oils would encourage the adoption of more modern agricultural practices by small farmers. The producers may also have access to agricultural raw materials, soft loans and family consumption goods. The strengthening of the regional economy through the increased income of family farmers, combined with the diversification of agricultural production, illustrates the potential of biodiesel production as a strategy for climate change adaptation. The vulnerability to climate change is determined by the level of susceptibility of a system (natural or human) in dealing with the negative aspects of climate change. In this context, the concept of susceptibility must be understood not only in terms of the amount of money needed to face this new reality, but also in terms of technical procedures and equipment adopted in subsistence farming. In the northeast, $>60 \%$ of family farmers' properties make use of manual technology, $6.3 \%$ employ soil conservation and only $2.7 \%$ take up technical assistance (INCRA/FAO 2000). In Brazil, biomass production may facilitate improvement of the livelihood of this target group, decreasing its vulnerability to climate change impacts.

On the mitigation side, climate change renews the urgency to stimulate viable options in energy production from biomass and to develop sustainable land use policies (Beg et al. 2002). Biodiesel is obtained from a chemical reaction (transesterification process) between oil and alcohol, with the aid of a catalyst. The alcohol used may be methanol or ethanol. Methanol is produced from natural gas or naphtha, an oil product, and thus is not a renewable product. Ethanol, in turn, is a renewable fuel, produced in Brazil from sugar cane. On the other hand, methanol has other economic advantages: it is more reactive, needs half the amount of ethanol to produce biodiesel, is cheaper, uses less energy and has greater yield (Parente 2006). European countries, for example, require that the biodiesel consumed there be manufactured with methanol. Nevertheless, the potential advantages of biodiesel for the environment are good, even when methanol is used for its production. Besides reducing $78 \%$ of $\mathrm{CO}_{2}$ emissions, the use of biodiesel reduces sulphur and particulate material emissions by between 98 and 50\%, respectively, when compared to the use of diesel oil (GTI 2003).

\section{BARRIERS TO BIODIESEL PRODUCTION AS AN AD-MIT STRATEGY, AND POLICY TOOLS TO OVERCOME THEM}

The insertion of small family farmers in the biodiesel production chain is characterized by a productive pattern of low productivity, deficient environment sustainability and low financial return. Barriers have been identified throughout the whole production chain, from crop to biofuel, showing that a strong governmental policy is needed to structure the biodiesel chain so that the PNPB social development targets can be met. The PNPB incentives are not sufficient to ensure the program's success.

Productive process organization and insertion of small farmers in the biodiesel market are both related to meeting the needs of these families, and therefore are dependent on established social relations. Agriculture represents not only an economic activity, but also an essential element that delineates the social identity of the farmer and his family. Family farmers are defined as those who use mostly manpower from members of a given family, in charge of both agricultural 
production and management tasks. Within this context, it is important to discuss how the child labor issue is dealt with in the region.

Different local stakeholders have diverse opinions regarding child labor, which raises a complex issue to be addressed in vegetable oil supply contracts. Sometimes, small farmers' children have a negative view of farming and would prefer to move to larger centers, creating social identity problems and putting family farming sustainability at risk. Research carried out in 2001 revealed that $34.8 \%$ of the children and teenagers in the northeast between 5 and $17 \mathrm{yr}$ old did not attend school, either as a result of their own choice, or that of their parents or guardians. Approximately 221000 children and teenagers in that age category were working; $78.7 \%$ of those working in agriculture are satisfied with the work (IBGE 2004). In the projects carried out by Petrobras, the contracts signed with family farmers included a clause prohibiting the inclusion of children in agricultural labor and emphasizing the need for them to go to school. Nonetheless, this measure by itself is not enough to guarantee that child labor will be eradicated, since huge monitoring and inspection difficulties remain.

Small farmers in semi-arid areas lack the basic technical prerequisites crucial to production development, such as equipment, electricity and access to water. Credit programs aimed at promoting vegetable oil production that actually reach small farmers could provide a starting point for fostering investment in the sustainable development of biodiesel production among small farmers in Brazil.

Economic limitations of small family farmers are evidenced by restricted access to machinery and other equipment, capital constraints and high environmental effects, such as soil depletion. Small farmers play a subordinate role, providing raw material, but with no opportunities of aggregating value. The organization of small family farmers through associations and cooperatives could help to structure agricultural production, reducing the risks faced by farmers and encouraging them to get actively engaged in the PNPB. This would help to fill institutional gaps and, consequently, help to meet the demands of biodiesel producers. In addition, stronger interactions between the institutions that have already been created is very important. Approximately $43 \%$ of the rural workers unions are located in the northeast, the highest regional percentage, which suggests that the creation of new associations in the northeast might not be sufficient to guarantee their effective participation in the PNPB, and that their lack of interaction should be dealt with (DIEESE 2006). Farmers may experience solid economic growth once they have learned more about the market they are engaged in and, thus, could play a much more important role than being mere producers in the biodiesel chain (Abramovay 1999). Therefore, technical assistance and capacity building through access to information, knowledge and training should be provided so that the insertion of small farmers in the process is self-sustained.

Contracts closed between farmers and potential vegetable oil seed purchasers are based on the use of large-capacity presses. Pressing oil in centralized industrial units will benefit the large purchasers of oil in natura instead of small farmers, who will become vulnerable to market price ups and downs. Medium term, indebted small farmers may be obliged to sell their property and move to large urban centers, as happened under the Brazilian program to produce the alcohol used to fuel vehicles. Furthermore, decentralized and small-capacity crushing units could facilitate the usage of by-products as fertilizers and animal food. Purchase and price guarantees can be given once an economically viable pressing facility is in operation. This will only be possible if the necessary production volume is supplied.

In contrast, the soybean production chain in Brazil is already structured, logistics exist and large volumes are produced. However, when it comes to the evaluation of the energy balance, soybean production is definitely not the best option. For biodiesel produced from soy oil and methanol, the energy output/input ratio falls within the range of 1.1 to 3.3 (Sheehan et al. 1998, Pimentel \& Patzek 2005). This ratio is between 2.0 and 2.7 in the case of castor beans and sunflower, with the same transesterification process using methanol.

From an economic point of view, when soybean and soy oil prices are low on the international market, as was the case in the first years after launching the PNPB, biodiesel production from soy oil is a complementary product for agribusiness and is economically advantageous; nevertheless, the social benefits are much lower in terms of job creation and income generation for the rural population. Brazil is the world's second major soybean producer, and increasing biodiesel demand may induce expansion of soy plantations in the country. In this case, the PNPB's incentives to include small farmers in the biodiesel market may be insufficient to guarantee social benefits to the semiarid rural population. Furthermore, the environmental benefits of the use of biodiesel may be offset by the expansion of soy plantations towards the Amazon region, with the risk of inducing deforestation.

The recent decision by the United States administration of supporting the production of ethanol from corn in the USA has led to an increase in corn and soybean prices on the international market. In the future, if soybean prices remain high, biodiesel production from soy oil may lose its cost effectiveness. 
The economic prospects for alternative vegetable oil crops, such as the purging nut, may be more promising as feedstocks for biodiesel production in medium- and long-term perspectives. Much agronomical research is still needed in this field, as very little experience exists in cultivating this crop in Brazil.

Preliminary results from Petrobras' technological research also suggest that there is much room for improvement in biodiesel production technology, including the use of alternative feedstocks, such as the direct production from seeds, as well as the use of byproducts, which may lead to lower production costs. In this new production process, which is still being developed, it would not be necessary to extract the oil, as the biodiesel would be produced in a reactor through the direct addition of an alcohol to crushed castor seeds. However, this process requires a greater use of energy, water and catalysts.

Biodiesel production from different feedstocks typically generates by-products with good market prices, such as organic fertilizer and animal fodder. Proper organization in marketing these by-products would substantially increase the economic competitiveness of biodiesel production by family farmers.

\section{CONCLUSIONS}

Biodiesel production from vegetable oils by small family farmers in the semi-arid region of northeast Brazil certainly exhibits great potential in simultaneously promoting climate change adaptation and mitigation and illustrates a good case for the Ad-Mit approach.

There are several crops suitable for small-scale production by family farmers. The feedstocks presented in Table 1 have several varieties available and selected seeds adapted to dry areas and high temperatures. They do not require mechanization, allow for crop rotation and-with the exception of cotton and sunflower-can be planted alongside subsistence crops (intercropping or rotational cropping). These plants are sufficiently robust to resist the severe drought conditions in this region, even if aggravated by climate change in a scenario of a $2^{\circ} \mathrm{C}$ average temperature increase in the northeast region (Marengo et al. 2007). Castor beans, peanuts, cotton, sunflower and the purging nut, among others, represent good prospects: assuming a $30 \%$ reduction in rainfall, all these crops can still survive in the semi-arid, northeastern region. Their social, economic and environmental benefits may be crucial to socially vulnerable groups, such as family farmers, also menaced by the drought conditions that are expected to be aggravated by climate change.
The main challenge remains the implementation of appropriate policies to overcome the existing barriers to more effective participation of small farmers in the PNPB and to achieve the required institutional setting, capacity building, technological and financial support, and logistics infrastructure.

The Brazilian government has announced the social inclusion of small farmers as a key priority of the program. However, so far, the policy tools implemented have been insufficient to ensure a meaningful contribution of family farmers to the Brazilian biodiesel production. Additional social policies, focused on overcoming the huge barriers still prevailing, will be required to meet this challenge. As illustrated by the ethanol program, which has been running in Brazil since 1975, technical and economic success does not ensure the social and environmental sustainability of bio-fuel production.

\section{LITERATURE CITED}

Abramovay R (2000) O capital social dos territórios: repensando o desenvolvimento rural. Economia Aplicada 4: 379-397

Beg N, Morlot JC, Davidson O, Afrane-Okesse Y and others (2002) Linkages between climate change and sustainable development. Clim Policy 2:129-144

de Carvalho O, dos Santos AJ (2003) Contribuição da 'Nova Sudene' para o desenvolvimento da região semi-árida do nordeste. Relatório Final, Recife

DIEESE (Departamento Intersindical de Estatística e Estudos Socioeconômicos Núcleo de Estudos Agrários e Desenvolvimento Rural) (2006) Estatísticas do meio rural. MDA, São Paulo

Freitas MAV (1999) O estado das águas no Brasil. Perspectivas de gestão e informação de recursos hídricos. Agência Nacional de Energia Elétrica-ANEEL, Sindicato Nacional do editores de Livros, Rio de Janeiro

GTI (Grupo de Trabalho Interministerial, Casa Civil da Presidência da República, Brazil) (2003) Relatório final-Anexo III. Imprensa oficial, Brasília, DF

IBGE (Instituto Brasileiro de Geografia e Estatística) (2004) Síntese de indicadores sociais. IBGE, Rio de Janeiro

IBGE (Instituto Brasileiro de Geografia e Estatística) (2006) Contas nacionais: produto interno bruto dos municípios 2004, No. 18. Diretoria de Pesquisas, Coordenação de Contas Nacionais, Ministério do Planejamento, Orçamento e Gestão, Rio de Janeiro

IBGE/PAM (Instituto Brasileiro de Geografia e Estatística/ Pesquisa Agrícola Municipal) (2005) Cereais, leguminosas e oleaginosas. IBGE, Rio de Janeiro

INCRA/FAO (Instituto Nacional de Colonização e Reforma Agrária) (2000) Novo retrato da agricultura familiar. O Brasil redescoberto. Ministério do Desenvolvimento Agrário/INCRA, Brasília

IPCC (Intergovernmental Panel on Climate Change) (2007) Climate change 2007: impacts, adaptation and vulnerability. Contribution of Working Group II to the 4th Assessment Report of the Intergovernmental Panel on Climate Change. Cambridge University Press, Cambridge

La Rovere EL, Simões AF (2008) Climate change implications of the Brazilian energy outlook. Terrae Campinas 3:4-15 
Leite SP (2005) Estado, padrão de desenvolviment e agricultura: o caso brasileiro. Estudos Sociedade e Agricultura (UFRJ), Rio de Janeiro 13:27-53

Marengo J (2005) Vulnerabilidade da agricultura do semiárido à variabilidade natural e a mudanças climáticas. In: Cadernos NAE (ed) Fevereiro, No. 3. Núcleo de Assuntos Estratégicos da Presidência da República, Secretaria de Comunicação de Governo e Gestão Estratégica, Brasília

Marengo JA, Nobre CA, Salati E, Ambrizzi T and others (2007) Mudanças climáticas globais e efeitos sobre a biodiversidade: caracterização do clima atual e definição das alterações climáticas para o território Brasileiro ao longo do Século XXI-Sumário técnico. MMA/SBF/DCBio, Basília, DF

Monteiro JMG (2007) Plantio de oleaginosas por agricultores familiares do semi-árido nordestino para produção de biodiesel como uma estratégia de mitigação e adaptação às

Submitted: July 12, 2008; Accepted: May 25, 2009 mudanças climáticas. Tese de Doutorado. Available at: www.ppe.ufrj.br

Parente EJdeS (2006) Biodiesel no plural. In: O futuro da indústria: biodiesel. Coletânea de Artigos, Série Política Industrial, Technológica e de Comércio 14, Brasília, DF

Pimentel D, Patzek TW (2005) Ethanol production using corn, switchgrass, and wood; biodiesel production using soybean and sunflower. Nat Resour Res 14:65-76

Sheehan J, Camobresco V, Duffield J, Graboski M, Shapouri $\mathrm{H}$ (1998) Overview of biodiesel and petroleum diesel life cycles. In: Life cycle inventory of biodiesel and petroleum diesel for use in an urban bus. National Renewable Energy Laboratory, US Department of Energy

UNDP (United Nations Development Program) (2006) Relatório do desenvolvimento humano 2006: a água pra lá da escassez: poder, pobreza e a crise mundial da água. www. pnud.org.br

Proofs received from author(s): November 22, 2009 